\title{
Bivalves of the family Unionidae in ox-bow lakes of the Bug River
}

\author{
Krzysztof LEWANDOWSKI \\ Institute of Biology, University of Podlasie, Siedlce, Poland; e-mail: krzysztof@bemo.waw.pl
}

\begin{abstract}
The occurrence of bivalves of the family Unionidae was analysed in 16 ox-bow lakes of the Bug River (The Bug River Valley Landscape Park) in the years 2003-2005. One to four species were found in 12 of the lakes. Unio pictorum (L.) was the dominating species in 5 and Anodonta anatina (L.) - in 3 lakes. Other frequent species were $U$. tumidus Philipsson and A. cygnea (L.). U. crassus Philipsson was found in only one of the ox-bow lakes. Most frequent densities noticed were around $10 \mathrm{ind} . / \mathrm{m}^{2}$ and the maximum density was over $200 \mathrm{ind} . / \mathrm{m}^{2}$.
\end{abstract}

Key words: Unionidae, Bug River, ox-bow, Bug River Valley Landscape Park, fauna, Poland

\section{INTRODUCTION}

The Bug in its middle and lower course is a lowland, naturally meandering river that flows far from large town centres and is only slightly affected by artificial regulation. It is one of the last large European rivers which preserved close to the natural status and its valley has high natural values. The character of the region is reflected by the existence of two landscape parks, numerous nature reserves and the status of ecological corridor of European importance (Rąkowski et al. 2002). Apart from islands, shoals, steep escarpments, the very common oxbow lakes are important elements of the landscape there. With the exclusion of aquatic macrophytes and birds, ox-bow lakes are poorly known; this is particularly true for aquatic invertebrates.

Bivalves of the family Unionidae, common in lakes (e.g. Widuto \& Kompowski 1968, Lewandowski \& Stańczykowska 1975, Kasprzak 1985, Lewandowski 1991), rivers (Piechocki 1969, 2002, Lewandowski 1990, 1996, Abraszewska-Kowalczyk 2002 and others) and dam reservoirs (e.g. Krzyżanek 1976, Jurkiewicz-Karnkowska 1989, Dusoge et al. 1999) are the biggest freshwater invertebrates in Poland. The occurrence of these bivalves in ox-bow lakes is practically unknown.

This study was aimed at analysing the occurrence of Unionidae in several ox-bow lakes of the Bug River.

\section{STUDY AREA AND METHODS}

The occurrence of bivalves of the family Unionidae was analysed in the years 2003-2005 in 16 selected ox-bow lakes, most of which were situated in the Bug River Valley Landscape Park (Fig. 1). The lakes are to a different degree joined with the river - from intensively flushed to totally and permanently cut-off from the river. Their surface area varied from less than 0.5 ha to c. 27 ha, and maximum depths - from 1 to $5 \mathrm{~m}$ (Table 1).

Ox-bow lakes were sampled with varying intensity. In six lakes samples were collected for $2-3$ subsequent years usually three times in a season (i.e. in spring, summer and autumn), - in 
the remaining lakes - once a year. Samples were taken from 2 to 5 sites depending on the lake's size. Usually the near-shore belt to the depth of $1 \mathrm{~m}$ was the sampling area.

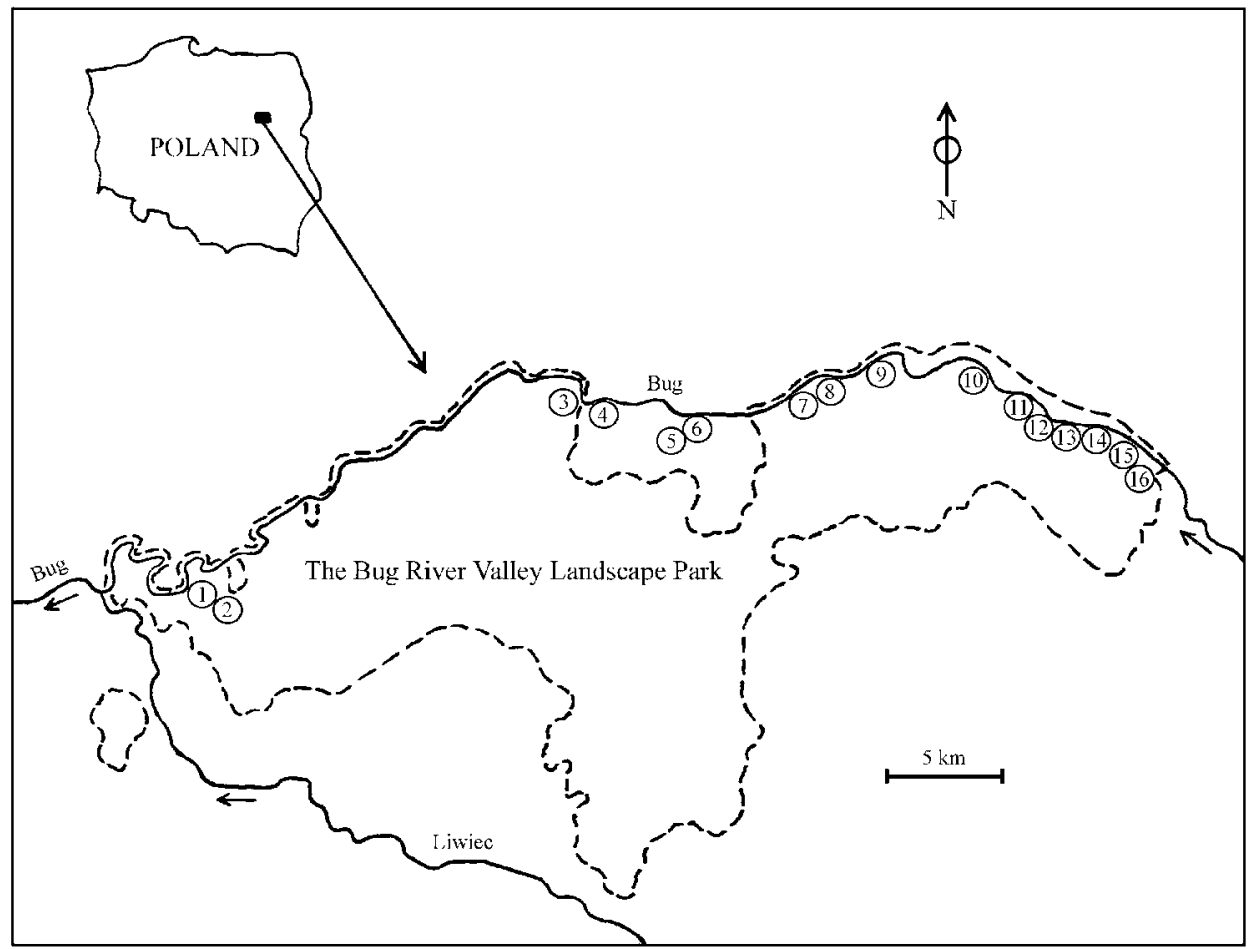

Fig. 1. Location of the studied ox-bow lakes (numbers as in Table 1).

Quantitative samples were taken with a frame of an area of $0.25 \mathrm{~m}^{2}$ (4 samples per site) from which bivalves were collected by hand or with the Bernatowicz's grab sampler of an area of $0.16 \mathrm{~m}^{2}$ (5 samples per site). At low densities of Unionidae these samples were supplemented with qualitative collections (with bottom drag or active search).

Species, size (measured with the calipers) and age (estimated from annual rings) of bivalves were determined in situ and live animals were returned to water in the same place since many species are legally protected. In total 2612 individuals of Unionidae were collected. Measured dimensions allowed for estimating biomass (wet weight including the shells) based on earlier numerous data.

\section{RESULTS}

Bivalves of the family Unionidae were present in 12 out of 16 analysed ox-bow lakes of the Bug River. Lakes devoid of these bivalves were usually small (1-3 ha) water basins isolated from the river course though in a very small ox-bow lake near Prostyń (lake number 5) of an area less than 0.5 ha as many as three species were found. In the remaining lakes $1-4$ species were recorded. They usually occurred in a near-shore zone less than $1 \mathrm{~m}$ deep. Occasional samplings along cross-section profiles at $0.5 \mathrm{~m}$ depth intervals revealed that only the nearshore zone was inhabited by the bivalves. 
Table 1. The occurrence of bivalves of the family Unionidae in ox-bow lakes of the Bug River.

\begin{tabular}{|c|c|c|c|c|c|c|c|c|}
\hline No & Ox-bow & $\begin{array}{c}\text { Area } \\
\text { (ha) }\end{array}$ & $\begin{array}{l}\text { Maximum } \\
\text { depth (m) }\end{array}$ & $\begin{array}{c}\text { Connection } \\
\text { with the Bug }\end{array}$ & $\begin{array}{l}\text { Number } \\
\text { of } \\
\text { sampling } \\
\text { sites }\end{array}$ & $\begin{array}{c}\text { Number } \\
\text { of } \\
\text { unionid } \\
\text { species }\end{array}$ & $\begin{array}{l}\text { Density in } \\
\text { the zone of } \\
\text { occurrence } \\
\text { (ind. } / \mathrm{m}^{2} \text { ) }\end{array}$ & $\begin{array}{c}\text { Fresh } \\
\text { biomass } \\
\text { (estimated) } \\
\left(\mathrm{g} / \mathrm{m}^{2}\right)\end{array}$ \\
\hline 1 & Szumin & 17.0 & 1.5 & strong & 3 & 4 & 124 & 4095 \\
\hline 2 & Wywłoka & 23.0 & 3.5 & strong & 5 & 4 & 208 & 4615 \\
\hline 3 & Bużysko-Morzyczyn & 25.0 & 2.0 & weak & 5 & 4 & 9 & 215 \\
\hline 4 & Glinki Lake & 6.0 & no data & missing & 3 & 3 & 56 & 1330 \\
\hline 5 & $\begin{array}{l}\text { Small water body near } \\
\text { Prostyń }\end{array}$ & $<0.5$ & no data & missing & 2 & 3 & 10 & 120 \\
\hline 6 & $\begin{array}{l}\text { Water body near the } \\
\text { railway bridge }\end{array}$ & 3.0 & no data & missing & 2 & 2 & 26 & 885 \\
\hline 7 & Borek Lake & 5.0 & no data & missing & 2 & 3 & 5 & 80 \\
\hline 8 & $\begin{array}{l}\text { Small water body near } \\
\text { Rytele Święckie }\end{array}$ & 1.0 & no data & missing & 2 & 0 & 0 & 0 \\
\hline 9 & $\begin{array}{l}\text { Channel near Rytele } \\
\text { Suche }\end{array}$ & 27.0 & no data & strong & 5 & 3 & 30 & 490 \\
\hline 10 & Wszebory & 12.0 & 1.0 & missing & 3 & 3 & 1 & 20 \\
\hline 11 & Przewóz Nurski & 23.0 & 5.0 & missing & 4 & 3 & 4 & 70 \\
\hline 12 & Białe Lake & 1.5 & 2.0 & missing & 3 & 0 & 0 & 0 \\
\hline 13 & Zagórze & 3.0 & no data & missing & 2 & 0 & 0 & 0 \\
\hline 14 & Kiełpiniec & 2.0 & no data & missing & 2 & 3 & 52 & 2750 \\
\hline 15 & Młynarze & 2.5 & no data & missing & 2 & 1 & 4 & 280 \\
\hline 16 & Białobrzegi & 2.0 & no data & missing & 2 & 0 & 0 & 0 \\
\hline
\end{tabular}

In six ox-bow lakes the density of Unionidae was relatively low (less than 10 ind. per $\mathrm{m}^{2}$ ), in two it was extremely high exceeding 100 ind. per $\mathrm{m}^{2}$ of the bottom within their zone of occurrence (Table 1). The highest density exceeded 200 bivalves per $\mathrm{m}^{2}$ and biomass was more than $4.5 \mathrm{~kg}$ per $\mathrm{m}^{2}$ (ox-bow lake no. 2 - Wywłoka). The lakes with highest densities of Unionidae had open connections with the Bug.

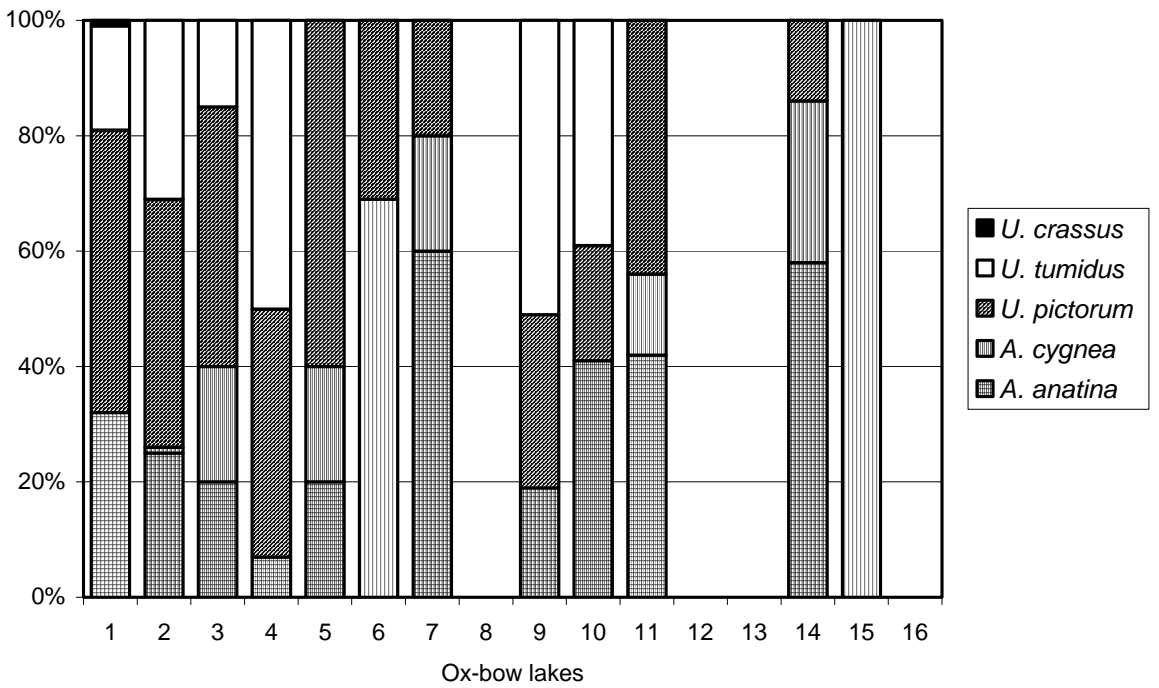

Fig. 2. Contribution of particular unionid species in ox-bow lakes of the Bug River. 
Unio pictorum (Linnaeus, 1758) dominated in 5 ox-bow lakes, Anodonta anatina (Linnaeus, 1758) in three and Unio tumidus Philipsson, 1788 and Anodonta cygnea (Linnaeus, 1758) dominated in two ox-bow lakes each (Fig. 2). Unio crassus Philipsson, 1788 (2 live specimen) was found only in ox-bow lake no. 1 in Szumin. It was most through-flow ox-bow lake of sandy bottom within the zone of occurrence of Unionidae.

Table 2. The smallest and largest lengths $(\mathrm{mm})$ of Unionidae in ox-bow lakes of the Bug River.

\begin{tabular}{|l|l|c|c|c|c|c|}
\hline No & \multicolumn{1}{|c|}{ Ox-bow } & $\begin{array}{c}\text { Anodonta } \\
\text { anatina }\end{array}$ & $\begin{array}{c}\text { Anodonta } \\
\text { cygnea }\end{array}$ & $\begin{array}{c}\text { Unio } \\
\text { pictorum }\end{array}$ & $\begin{array}{c}\text { Unio } \\
\text { tumidus }\end{array}$ & $\begin{array}{c}\text { Unio } \\
\text { crassus }\end{array}$ \\
\hline 1 & Szumin & $24-106$ & - & $42-96$ & $32-95$ & $75-78$ \\
2 & Wywłoka & $27-115$ & 150 & $21-97$ & $27-98$ & - \\
3 & Bużysko-Morzyczyn & $33-105$ & $53-155$ & $51-87$ & $58-76$ & - \\
4 & Glinki Lake & $53-78$ & - & $59-87$ & $63-84$ & - \\
5 & Small water body near Prostyń & - & 78 & $46-58$ & 53 & - \\
6 & Water body near the railway bridge & - & $78-130$ & $37-84$ & - & - \\
7 & Borek Lake & $51-81$ & 69 & $51-85$ & - & - \\
9 & Channel near Rytele Suche & $50-96$ & - & $43-80$ & $50-75$ & - \\
10 & Wszebory & $51-85$ & - & $39-57$ & $60-80$ & - \\
11 & Przewóz Nurski & $46-74$ & 80 & $39-69$ & - & - \\
14 & Kiełpiniec & $19-107$ & $73-119$ & $60-91$ & - & - \\
15 & Młynarze & - & $134-136$ & - & - & - \\
\hline
\end{tabular}

The biggest $A$. cygnea were $130-155 \mathrm{~mm}$ long (ox-bow lakes no. $2,3,6,15$ ) and 11 years of age, A. anatina - 105-115 mm (ox-bow lakes no. 1, 2, 3, 14), U. pictorum - 90-97 mm (oxbow lakes no. 1, 2, 14), U. tumidus - 84-98 mm (ox-bow lakes no. 1, 2, 4). U. crassus reached almost $78 \mathrm{~mm}$ in length and 7 years of age (Tables $2 \& 3$ ).

Table 3. Sizes and age of the biggest Unionidae found in ox-bow lakes of the Bug in the years 2003-2005.

\begin{tabular}{|l|c|c|c|c|l|c|}
\hline \multicolumn{1}{|c|}{ Species } & $\begin{array}{c}\text { Length } \\
(\mathrm{mm})\end{array}$ & $\begin{array}{c}\text { Width } \\
(\mathrm{mm})\end{array}$ & $\begin{array}{c}\text { Height } \\
(\mathrm{mm})\end{array}$ & $\begin{array}{c}\text { Age } \\
(\text { years })\end{array}$ & \multicolumn{1}{|c|}{ Ox-bow } & Date \\
\hline A. anatina & 115.0 & 42.3 & 62.2 & 10 & Wywłoka & 14.07 .2003 \\
A. cygnea & 155.0 & 45.0 & 61.0 & 11 & $\begin{array}{l}\text { Bużysko- } \\
\text { Morzyczyn }\end{array}$ & 25.08 .2004 \\
& & & & 10 & Wywłoka & 13.10 .2004 \\
U. pictorum & 97.5 & 30.8 & 41.9 & 11 & Wywłoka & 25.08 .2004 \\
U. tumidus & 98.1 & 30.4 & 46.0 & 7 & Szumin & 11.08 .2003 \\
U. crassus & 77.7 & 29.6 & 41.9 & \multicolumn{2}{|r}{} \\
\hline
\end{tabular}

\section{DISCUSSION}

Densities of Unionidae recorded in ox-bow lakes of the Bug did not markedly differ from those noted in other freshwater habitats though the values of 50-200 ind. per $\mathrm{m}^{2}$ should be considered very high (Table 1 ).

In lakes and dam reservoirs bivalves reach the densities of several to several dozen individuals per $\mathrm{m}^{2}$. In the eutrophic lake Zbęchy (Wielkopolska) Kasprzak (1985) found 16 ind. $/ \mathrm{m}^{2}$ on average. Maximum 7 ind. $/ \mathrm{m}^{2}$ and mean - less than 1 ind. $/ \mathrm{m}^{2}$ were found in Lake Mikołajskie (Lewandowski \& Stańczykowska 1975, Lewandowski 1991). In small lakes along the Krutynia River (Masurian Lakeland) the highest densities of $100 \mathrm{ind} . / \mathrm{m}^{2}$ and biomasses of $3.2 \mathrm{~kg} / \mathrm{m}^{2}$ were noted and in small lakes of the Szeszupa drainage basin (Suwalskie Lakeland) - 30 ind. $/ \mathrm{m}^{2}$ but usually less than 10 ind. $/ \mathrm{m}^{2}$ (Lewandowski 1990, 1996). Data of Widuto \& Kompowski (1968), who found c. 250 ind. $/ \mathrm{m}^{2}$ in one of the sites in Lake Kortowskie near Olsztyn should be considered exceptional. 
In Goczałkowicki dam reservoir several to several dozen Unionidae were found per $\mathrm{m}^{2}$ of the bottom (e.g. Krzyżanek 1989, 1994), and in Zegrzyński dam reservoir their densities did not exceed 20 ind. $/ \mathrm{m}^{2}$ (Dusoge et al. 1999).

Adult Unionidae aggregate for reproduction in rivers on relatively small areas forming shoals, beyond which their densities are practically zero. Piechocki (1969) described in details such a shoal in the Grabia River. In the Szeszupa River the densities often exceeding 100 ind. $/ \mathrm{m}^{2}$ and maximum values of 350 ind. $/ \mathrm{m}^{2}$ (maximum biomass of $7.2 \mathrm{~kg} / \mathrm{m}^{2}$ ) were recorded (Lewandowski 1990).

High densities and biomasses of Unionidae in ox-bow lakes of the Bug show favourable habitat conditions prevailing in many of these water bodies. Additional evidence for this is the relatively large sizes and old age achieved by individuals of particular species, specifically by protected A. cygnea. That situation is quite different from that in many lakes where the dwarfing of Unionidae (Lewandowski 1991, Piechocki \& Dyduch-Falniowska 1993) was observed.

The situation of Unionidae in ox-bow lakes of the Bug River (many species, old animals of large size, the presence of protected species, particularly of $U$. crassus, the only Polish species of the family Unionidae which is strictly protected acc. to European Communities Directive on the protection of natural habitats and wildlife flora and fauna) indicates the high natural quality of these water bodies mostly protected within the Bug River Valley Landscape Park.

\section{REFERENCES}

ABRASZEWSKA-KowAlCZYK A. 2002. Unionid bivalves of the Pilica River catchment area. Folia Malacol. 10: 99173.

Dusoge K., LEWANDOWSKI K. \& STAŃCZYKOWSKA A. 1999. Benthos of various habitats in the Zegrzyński Reservoir (central Poland). Acta Hydrobiol. 41: 103-116.

JURKIEWICZ-KARNKOWSKA E. 1989. Occurrence of molluscs in the littoral zone of the Zegrzyński Reservoir and in the pre-mouth and mouth zones of supplying rivers. Ekol. Pol. 37: 319-336.

KASPRZAK K. 1985. Occurrence and role of bivalves of the family Unionidae (Mollusca, Bivalvia) in the eutrophic Lake Zbęchy (Wielkopolska - Kujawy Lowland) and its outflow canal. Acta Hydrobiol. 27: 351-370.

KRZYŻANEK E. 1976. Preliminary investigations on bivalves (Bivalvia) of the dam reservoir Goczałkowice. Acta Hydrobiol. 18: 61-73.

KRZYŻANEK E. 1989. Rola małży rodziny Unionidae w Zbiorniku Goczałkowickim. Wszechświat 3: 57-59.

KRZYŻANEK E. 1994. Changes in the bivalve groups (Bivalvia - Unionidae) in the Goczałkowice Reservoir (southern Poland) in the period 1983-1992. Acta Hydrobiol. 6: 103-113.

LEWANDOWSKI K. 1990. Unionidae of Szeszupa River and of the lakes along its course in Suwalski Landscape Park. Ekol. Pol. 38: 271-286.

LEWANDOWSKI K. 1991. Long-term changes in the fauna of family Unionidae bivalves in the Mikołajskie Lake. Ekol. Pol. 39: 265-272.

LEWANDOWSKI K. 1996. Występowanie Dreissena polymorpha (Pall.) oraz małży z rodziny Unionidae w systemie rzeczno-jeziornym Krutyni (Pojezierze Mazurskie). Zeszyty Naukowe Komitetu „Człowiek i Środowisko” 13: $173-185$.

LEWANDOWSKI K. \& STAŃCZYKOWSKA A. 1975. The occurrence and role of bivalves of the family Unionidae in Mikołajskie Lake. Ekol. Pol. 23: 317-334.

PieCHOCKi A. 1969. Obserwacje biologiczne nad małżami z rodziny Unionidae w rzece Grabi. Acta Hydrobiol. 11: 56-67.

PIECHOCKI A. 2002. Populacja Unio crassus Philipsson, 1788 (Bivalvia, Unionidae) z środkowej Brdy [The population of Unio crassus Philipsson, 1788 (Bivalvia, Unionidae) in the middle course of the Brda River]. In: ŁAWRYNOWicz M., RózGa B. (eds), Tucholski Park Krajobrazowy 1985-2000. Stan poznania: 459-470. Wydawnictwo Uniwersytetu Łódzkiego, Łódź, 558 pp.

Piechocki A. \& Dyduch-FALniowska, 1993. Mięczaki (Mollusca), Małże (Bivalvia). Fauna Słodkowadna Polski. 7A. PWN, Warszawa-Poznań,187 pp.

Rąkowski G., Smogorzewska M., Janczewska A., Wójcik J., Walczak M. \& Pisarski Z. 2002. Parki Krajobrazowe w Polsce. Instytut Ochrony Środowiska, Warszawa, 719 pp.

WidUTO J. \& KomPOWSKI A. 1968. Badania nad ekologią małżów z rodziny Unionidae w Jeziorze Kortowskim. Zesz. nauk. WSR. Olsztyn 24: 479-497. 


\section{[Małże z rodziny Unionidae w starorzeczach Bugu]}

W latach 2003-2005 analizowano występowanie małży z rodziny Unionidae (skójkowate) w 16 starorzeczach Bugu, z których większość znajdowała się na terenie Nadbużańskiego Parku Krajobrazowego (Tab. 1). W 12 starorzeczach stwierdzono obecność od 1 do 4 gatunków. Były to: Anodonta anatina (L.) (szczeżuja pospolita), A. cygnea (L.) (szczeżuja wielka), Unio pictorum (L.) (skójka malarska) - gatunek dominujący w największej liczbie starorzeczy, U. tumidus Philipsson (skójka zaostrzona) i U. crassus Philipsson (skójka gruboskorupowa) - gatunek notowany tylko w jednym starorzeczu. Przeważnie notowano kilka-kilkanaście skójek i szczeżuj na $1 \mathrm{~m}^{2}$ dna w przybrzeżnej strefie zbiorników. Maksymalne zagęszczenia przekraczały 200 osobników na $1 \mathrm{~m}^{2}$, a maksymalną biomasę oszacowano na ok. $4,5 \mathrm{~kg} / \mathrm{m}^{2}$. Małże osiagały znaczne rozmiary - w przypadku szczeżui wielkiej była to długość maksymalna $155 \mathrm{~mm}$ (Tab. 3). Bogata fauna skójkowatych odzwierciedla wysokie walory przyrodnicze starorzeczy Bugu. 